University of Nebraska - Lincoln

DigitalCommons@University of Nebraska - Lincoln

\title{
Seasonal and spatial patterns of metals at a restored copper mine site. I. Stream copper and zinc
}

\author{
Dustin G. Bambic \\ University of California - Davis, dustinb@lwa.com \\ Charles N. Alpers \\ U.S. Geological Survey, cnalpers@usgs.gov \\ Peter G. Green \\ University of California - Davis \\ Eileen Fanelli \\ East Bay Municipal Utility District \\ Wendy K. Silk \\ University of California - Davis
}

Follow this and additional works at: https://digitalcommons.unl.edu/usgsstaffpub

Part of the Earth Sciences Commons

Bambic, Dustin G.; Alpers, Charles N.; Green, Peter G.; Fanelli, Eileen; and Silk, Wendy K., "Seasonal and spatial patterns of metals at a restored copper mine site. I. Stream copper and zinc" (2006). USGS Staff -Published Research. 478.

https://digitalcommons.unl.edu/usgsstaffpub/478

This Article is brought to you for free and open access by the US Geological Survey at DigitalCommons@University of Nebraska - Lincoln. It has been accepted for inclusion in USGS Staff -- Published Research by an authorized administrator of DigitalCommons@University of Nebraska - Lincoln. 


\title{
Seasonal and spatial patterns of metals at a restored copper mine site. I. Stream copper and zinc
}

\author{
Dustin G. Bambic $^{\mathrm{a}, *}$, Charles N. Alpers ${ }^{\mathrm{b}}$, Peter G. Green ${ }^{\mathrm{c}}$, \\ Eileen Fanelli ${ }^{\mathrm{d}}$, Wendy K. Silk ${ }^{\mathrm{a}}$ \\ ${ }^{a}$ Department of Land, Air, and Water Resources, University of California, Davis, CA 95616, USA \\ ${ }^{\mathrm{b}}$ U.S. Geological Survey, Placer Hall, $6000 \mathrm{~J}$ Street, Sacramento, CA 95819-6129, USA \\ ${ }^{\mathrm{c}}$ Department of Civil and Environmental Engineering, University of California, Davis, CA 95616, USA \\ ${ }^{\mathrm{d}}$ East Bay Municipal Utility District, 375 11th Street MS 704, Oakland, CA 94607, USA
}

Received 27 September 2005; received in revised form 31 January 2006; accepted 19 February 2006

Seasonal hydrology and benthic sediments control copper and zinc concentrations in a stream through a restored mine site.

\begin{abstract}
Seasonal and spatial variations in metal concentrations and $\mathrm{pH}$ were found in a stream at a restored copper mine site located near a massive sulfide deposit in the Foothill copper-zinc belt of the Sierra Nevada, California. At the mouth of the stream, copper concentrations increased and $\mathrm{pH}$ decreased with increased streamflow after the onset of winter rain and, unexpectedly, reached extreme values 1 or 2 months after peaks in the seasonal hydrographs. In contrast, aqueous zinc and sulfate concentrations were highest during low-flow periods. Spatial variation was assessed in $400 \mathrm{~m}$ of reach encompassing an acidic, metal-laden seep. At this seep, $\mathrm{pH}$ remained low (2-3) throughout the year, and copper concentrations were highest. In contrast, the zinc concentrations increased with downstream distance. These spatial patterns were caused by immobilization of copper by hydrous ferric oxides in benthic sediments, coupled with increasing downstream supply of zinc from groundwater seepage. Published by Elsevier Ltd.
\end{abstract}

Keywords: Hydrology; Copper; Zinc; pH; Water quality; Restored mine site; Seasonal variation; Spatial variation

\section{Introduction}

This paper reports the seasonal and spatial patterns in copper, zinc, and $\mathrm{pH}$ in Hinckley Run, the major watercourse through a restored mine site, Penn mine, located in the Sierra Nevada foothills near the town of Campo Seco in Calaveras County, California, USA. The area is part of the Foothill Copper-Zinc belt of massive sulfide deposits within the western Sierra Nevada range (Peterson, 1985). Penn Mine was opened in 1861 and operated intermittently until

DOI of original article: 10.1016/j.envpol.2006.02.018.

* Corresponding author. Present address: Larry Walker Associates, 250 Lafayette Circle, Suite 200, Lafayette, CA 94549, USA. Tel.: +1 925962 9700; fax: +19259629701 .

E-mail address: dustinb@1wa.com (D.G. Bambic). abandonment in 1953 (Clark and Lydon, 1962). The mine was the largest in the Foothill copper-zinc belt, with total production of more than 880,000 metric tons of ore. Acidic, metal-rich surface runoff from the mine, resulting primarily from the oxidation of sulfide minerals in surface waste piles, affected the Mokelumne River basin after mining began in the 1860s. Fish kills were documented in the Mokelumne River in the 1930s (Finlayson and Rectenwald, 1978). Built for flood control and recreational uses, Camanche Reservoir was completed in 1963, flooding the reach of the Mokelumne River adjacent to the Penn mine site. Approximately $200,000 \mathrm{~m}^{3}$ of zinc-rich, base-metal slag deposits are located along the shoreline of Camanche Reservoir, adjacent to the site of the Penn mine and its three historical smelters (Parsons et al., 2001). Impoundments on the mine site, built to improve water quality in the late 1970 s, were not sufficient to prevent 
periodic discharges of acidic, metal-rich water. In the early 1990s litigation against the East Bay Municipal Utility District (EBMUD) and the California Regional Water Quality Control Board (RWQCB) - Central Valley Region led to a judicial decision that the Mine Run Dam spillway constituted a point source requiring a National Pollutant Discharge Elimination System (NPDES) permit under the United States federal Clean Water Act.

In the late 1990s as part of a settlement to the litigation, US\$10 million was invested by EBMUD and the RWQCB to restore the Penn mine site by removing waste rock and mine tailings responsible for generating the acidic discharges into Camanche Reservoir. By December 2000, after approximately $291,000 \mathrm{~m}^{3}$ of waste material was excavated and deposited in a lined, on-site landfill, all impoundments were removed, natural stream channels and surface water flow were restored, and more than 10.5 hectares of riparian habitat were enhanced. The soil in the restored areas is a rocky/gravelly clay loam, originally a subsoil from the upstream landfill area, amended during restoration with "fertilizer mix" of organic compost, $336 \mathrm{~kg}$ per hectare of ureaform, $244 \mathrm{~kg}$ per hectare potassium sulfate, $482 \mathrm{~kg}$ per hectare gypsum, and $390 \mathrm{~kg}$ per hectare treble phosphate. After removal of the mine waste and restoration of the riparian habitat, the annual mass discharges of copper and zinc from the Penn mine site were reduced by $9000 \mathrm{~kg}$ $(99 \%)$ and 36,000 kg (92\%), respectively (CH2M Hill, 2001, 2003). Although the base-metal slag deposits adjacent to Camanche Reservoir were not removed, the Hinckley Run portion of the mine site is now considered to be close to its pre-mining condition. However, like many natural surface waters in exposed/disturbed mineralized environments, the drainages of Penn mine are still acidic and metalliferous. Since remediation, copper and zinc concentrations in Hinckley Run have reached maximum values of $20 \mathrm{mg} \mathrm{L}^{-1}$ and $130 \mathrm{mg} \mathrm{L}^{-1}$, respectively, with $\mathrm{pH}$ values often falling below 3 . This compares to California Toxics Rule (CTR) objectives of $0.009 \mathrm{mg} \mathrm{L}^{-1}$ for copper and $0.12 \mathrm{mg} \mathrm{L}^{-1}$ for zinc in aquatic systems (USEPA, 1997).

This study was inspired by a series of post-restoration monitoring reports that document the effectiveness of the restoration process in reducing the total loading of copper and zinc from the site to Camanche Reservoir (CH2M Hill, 2000, 2001, 2003). In this paper we explore the temporal and spatial variation of metals transported within the local watershed. Because seepage from a mineralized area intersected by deep mine workings contributes water to the downstream segment of the watercourse (Alpers et al., 1999), differences in chemistry upstream and downstream from the seepage area should provide insight about the mechanisms controlling the surface-water chemistry. The upstream section of Hinckley Run is not affected by subsurface seeps and thus provides an on-site (and in-stream) reference site (Bambic, 2003). The objective was to analyze the way in which the seep, soils, and stream interact to affect the concentrations of dissolved copper and zinc in the stream. Effects on riparian vegetation are considered in a companion paper (Silk et al., 2006).

\section{Materials and methods}

\subsection{Monitoring frequency and location}

The flow in Hinckley Run is dominated by runoff from rainfall in storms that occur mostly between November and April each year. With this in mind, we chose to sample every two to four weeks throughout the rainy season, continuing to the beginning of the dry season of 2002-2003. For data consistency, and to best represent seasonal variations on the time scale of weeks, storm events were avoided. The sampling dates were: 11/17/02, 1/17/03, 1/29/03, $2 / 19 / 03,3 / 7 / 03,3 / 25 / 03,4 / 14 / 03,5 / 15 / 03,6 / 3 / 03$, and 7/7/03. Additional samples of stream water and sediment were taken on 7/21/04 to characterize partitioning of metals between stream sediment and surface water during low-flow conditions.

A significant portion of annual metal loading probably occurs during highflow storm events, including first-flush effects (e.g. Jambor et al., 2000 and references therein). However, the sampling design was also chosen to serve a companion study of metal uptake in plants near Hinckley Run (Bambic, 2003; Silk et al., 2006), and the inter-storm conditions were sampled as more typical of the seasonal availability of metals to the plants. In comparison, the grab samples collected by EBMUD for post-restoration monitoring were collected monthly during non-storm events from $11 / 9 / 99$ to $8 / 26 / 02$.

Hinckley Run, as it traverses the Penn mine site, lies at the base of a steeply sloping watershed, and is approximately $0.8 \mathrm{~m}$ wide throughout its watercourse. To supplement the data available from EBMUD monitoring, three primary locations along Hinckley Run, all upstream from the EBMUD sampling location, were chosen for the detailed sampling. The locations of the four primary sampling spots within Hinckley Run were: just downstream of the first seep discharging to Hinckley Run, $85 \mathrm{~m}$ upstream from the seep, $126 \mathrm{~m}$ downstream from the seep, and $223 \mathrm{~m}$ downstream from the seep, as shown in Fig. 1, where the sites are labeled "seep," "upstream," "downstream," and "gage," respectively.

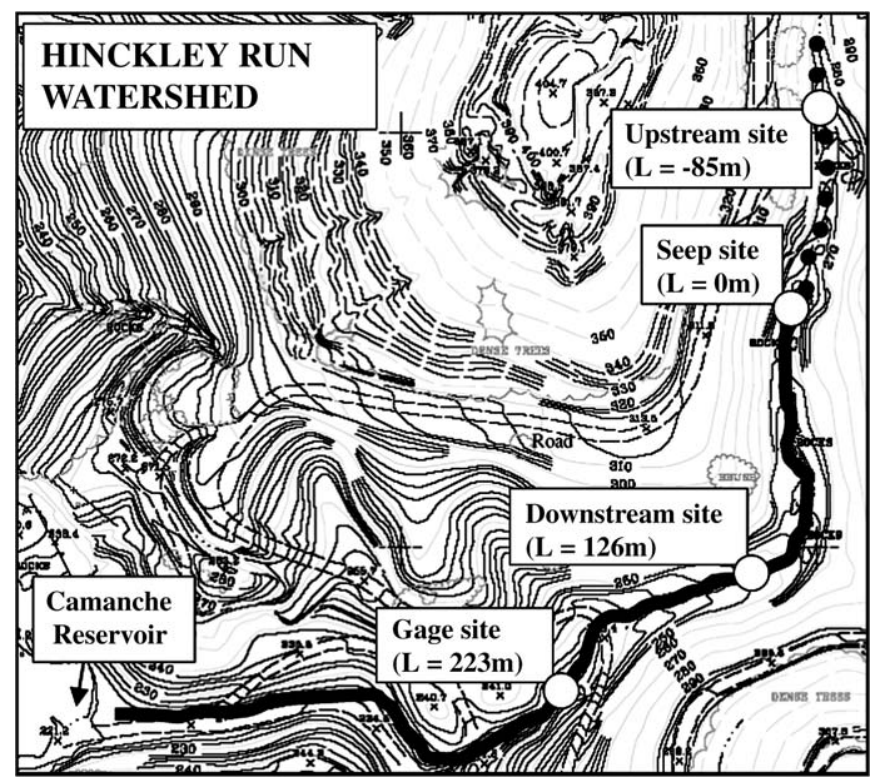

Fig. 1. Field site geography. Diagram of Hinckley Run, a stream with perennial (solid line) and intermittent (circles) segments traversing an abandoned mine site. To determine restoration effectiveness, metals, water quality, and flow rate were monitored for 34 months (1999-2002) at a gage station operated by East Bay Municipal Utility District at the mouth of the stream (gage, $L=223 \mathrm{~m}$ ). For most of the 2002-2003 water year, stream water was sampled by authors at a perennial seep (seep, $L=0$ ) and at sites upstream (upstream, $L=-85 \mathrm{~m}$ ) and downstream from the seep (downstream, $L=126 \mathrm{~m}$ ) as indicated on the diagram. Topographic contours are 2- and 10-foot intervals. For maps showing relation of Hinckley Run to Penn mine underground workings and surface waste piles (prior to their removal) see Alpers et al. (1999). 
The seep, located where the groundwater table usually intersects Hinckley Run, was a point of primary interest. It flows abundantly in the wet season when the surrounding water table rises and often flows also in the summer and fall months. The bedrock in this area is mineralized, hydrothermally altered, and weathered. Possible sources of dissolved metals at the seep are groundwater from underground mine workings, and groundwater that is affected by interaction with the mineralized bedrock in the highly altered and fractured zone.

The reach of Hinckley Run above the seep (represented in Fig. 1 by a dotted line) is losing and intermittent. Water quality at the intermittent upstream site ( $L=-85 \mathrm{~m}$ ) was not affected by groundwater seepage; this site is not underlain by reactive bedrock nor was it used during mining operations as a waste-rock disposal area. Thus the upstream site served as a reference site unaffected by acid rock drainage. In contrast, downstream from the seep $(L=0 \mathrm{~m})$, Hinckley Run is gaining and perennial (solid line in Fig. 1) and is affected by several buried seeps as well as the emergent seep sampled in our study. The intermediate ( $L=126 \mathrm{~m}$ ) downstream sampling point captured the effect of the local watershed on Hinckley Run and the resulting contribution to (or removal or dilution of) the inputs from the mineralized zone. In addition to the three primary locations, surface water was also sampled periodically at the gage site $(L=223 \mathrm{~m})$. Discharge data were collected monthly using a weir at the gage site during the post-restoration monitoring program in 1999-2002. Continuous flow recording equipment was installed by EBMUD at the gage site in 2002 and used for the study period 2002-2003. Daily average discharge data and a two-week running average of discharge were used in analysis of discharge and the stream chemistry, based on approximately bi-weekly surface-water grab samples.

\subsection{Water quality measurements}

Water sampled at the mouth of the stream during the post-restoration monitoring program 1999-2002 was assayed for $\mathrm{Cu}$ and $\mathrm{Zn}$ by EPA method 200.7 (USEPA, 1994) and for sulfate by EPA method 300.0 (USEPA, 1993). Water was sampled at each of the three principal sampling sites $(L=-85 \mathrm{~m}, 0 \mathrm{~m}$, and $126 \mathrm{~m}$ ) during each of the field visits during 2002-2003, as itemized above. Stream $\mathrm{pH}$ was measured in situ with a calibrated meter and combination electrode. Filtered $(0.22 \mu \mathrm{m}$ pore size $)$ and unfiltered samples were collected and acidified (in the field) with $1 \mathrm{M}$ Fisher Trace Metal Grade $\mathrm{HNO}_{3}$ (Pittsburgh, PA). Samples were chilled on wet ice in the field and refrigerated in the laboratory until analysis. Note that water was available for sampling at the site upstream from the seep $(L=-85 \mathrm{~m})$ on only $1 / 17 / 03,2 / 19 / 03$, and 4/14/03.

Elemental concentrations in the stream water were analyzed with an Agilent 7500i ICP-MS (Palo Alto, CA). The ICP-MS instrument was calibrated for more than 20 elements and showed a linear fit of 0.9999 or better for all elements over four orders of magnitude (100 pptr to $1 \mathrm{ppm}$ ). The ICP-MS was tuned each day for robust operation, especially for low molecular ions demonstrated by $\mathrm{CeO} / \mathrm{Ce}=0.4 \%$. For each of the four analysis batches, three standard solutions were used for calibration: NIST 1640 (a certified standard reference material representing a mine-impacted creek), a $500 \mathrm{ppb} \mathrm{Zn}$ solution, and a $10 \mathrm{ppm}$ $\mathrm{Cu}$ solution. The calculated $\mathrm{Zn}$ concentrations for the samples were very similar (within 10\%) for assays based on ${ }^{64} \mathrm{Zn}$ and ${ }^{66} \mathrm{Zn}$, and the calculated $\mathrm{Cu}$ values were also within $10 \%$ for ${ }^{63} \mathrm{Cu}$ and ${ }^{65} \mathrm{Cu}$. An average of results for the two isotopes is displayed in the figures for each element. During auto-sampling on the ICP-MS instrument, a rinse was performed between every sample, and after every ninth sample, the rinse solution was analyzed to verify minimal carry-over. Instrument detection limits $(p<0.01)$ were less than $0.00005 \mathrm{mg} \mathrm{L}^{-1}$ for $\mathrm{Cu}$ and $\mathrm{Zn}$ following EPA method 6020. Analytical precision was better than 5\% based on the relative percentage difference of frequent replicate analyses.

\subsection{Characterization of solids}

In July 2004, stream-bed sediment and efflorescent salts on stream banks and rocks protruding above stream-level water were collected at three downstream locations: $L=0 \mathrm{~m}$ (seep), $L=111 \mathrm{~m}$ and $L=126 \mathrm{~m}$. At the time of sampling, these sites exhibited stream pH values of 3.0, 2.7 and 6.1, respectively. Subsamples $(\sim 0.1 \mathrm{~g}$ dry weight $)$ from the sediment and salt samples were weighed and digested in deionized water to which $1 \mathrm{~mL}$ of $\mathrm{HNO}_{3}$ and 1 to $5 \mathrm{~mL}$ of $\mathrm{HCl}$ were added as necessary to dissolve the sedimentary material before diluting to $100 \mathrm{~mL}$. Solutions were analyzed as before with ICP-MS.
Efflorescent salt samples were analyzed by powder X-ray diffraction (XRD) using a Scintag PAD5 diffractometer with solid-state detector. $\mathrm{Cu}-\alpha$ radiation was used with run conditions of $40 \mathrm{~mA}$ and $45 \mathrm{kV}$. The step size was $0.02^{\circ} 2 \theta$ with a count time of $1.5 \mathrm{~s}$. Iron-rich stream-bed sediments were analyzed by powder XRD using an INEL diffractometer with a CP120 positive position detector, collecting data from $2-120^{\circ} 2 \theta$. Cu- $\alpha$ radiation was used with run conditions of $30 \mathrm{~mA}$ and $30 \mathrm{kV}$. Data were analyzed using JADE 6.1 software (Materials Data Inc., Livermore, CA) and the PDF-2 data file (International Center for Diffraction Data, Newtown Square, PA).

\section{Results}

\subsection{Temporal variation of copper, zinc, sulfate, and $\mathrm{pH}$}

Post-restoration effectiveness monitoring reports $(\mathrm{CH} 2 \mathrm{M}$ Hill, 2000, 2001, 2003) revealed seasonal variations in $\mathrm{pH}$ and the concentrations of metals and sulfate at the mouth of Hinckley Run (Fig. 2). The onset of winter rains, and the associated increase in groundwater elevation and stream discharge, were closely followed by a drop in $\mathrm{pH}$ and an increase in dissolved copper concentration. Further decreases in $\mathrm{pH}$ and increases in copper concentration occurred along the receding limbs of the seasonal hydrograph so that $\mathrm{pH}$ minima and copper maxima occurred 1 or 2 months after the peaks in stream water discharge. In contrast, dissolved zinc concentrations were less variable than copper, generally highest during low flows, and correlated with sulfate concentrations but not with $\mathrm{pH}$.

\subsection{Spatial variation of copper, zinc, and $p H$}

The sampling during 2002-2003 reveals a systematic spatial variation in copper and zinc in Hinckley Run (Fig. 3). Stream discharge peaked twice in December 2002 and again in late April 2003. The seep has a large effect on stream copper, as aqueous copper concentrations were always highest at the seep. The seep also affects the spatial and temporal patterns of stream $\mathrm{pH}$. The $\mathrm{pH}$ at the seep was relatively constant over the year, ranging from 2.5 to 3.2. However, the $\mathrm{pH}$ downstream from the seep was highly variable, with near-neutral values during the dry season falling to values less than 3.5 measured in January and May 2003 at sampling site $L=126 \mathrm{~m}$, about 3 weeks after the rainstorms in December 2002 and late April 2003 , respectively. The highest copper concentrations downstream from the seep during 2002-2003 were associated with low-pH conditions in January and February 2003 (Fig. 3). However, the low $\mathrm{pH}$ condition observed during May 2003 was not associated with high copper concentration.

We hypothesize that the higher $\mathrm{pH}$ in downstream reaches during the dry season resulted in fixation of copper on streambed sediments, highly limiting the mobility of copper. The streambed sediments were found to consist of poorly crystalline, hydrous ferric oxide (HFO) minerals (possibly schwertmannite and/or ferrihydrite), based on powder XRD and wet chemistry. During the seasonally dry period on November 17 , 2002 and July 7, 2003, copper concentrations precipitously decreased by $94 \%$ and $97 \%$, respectively over a reach of only $126 \mathrm{~m}$ in Hinckley Run between the seep $(L=0 \mathrm{~m})$ and the downstream site $(L=126 \mathrm{~m})$. Sediment sampling confirmed 
Penn Mine, Hinckley Run 1999-2002

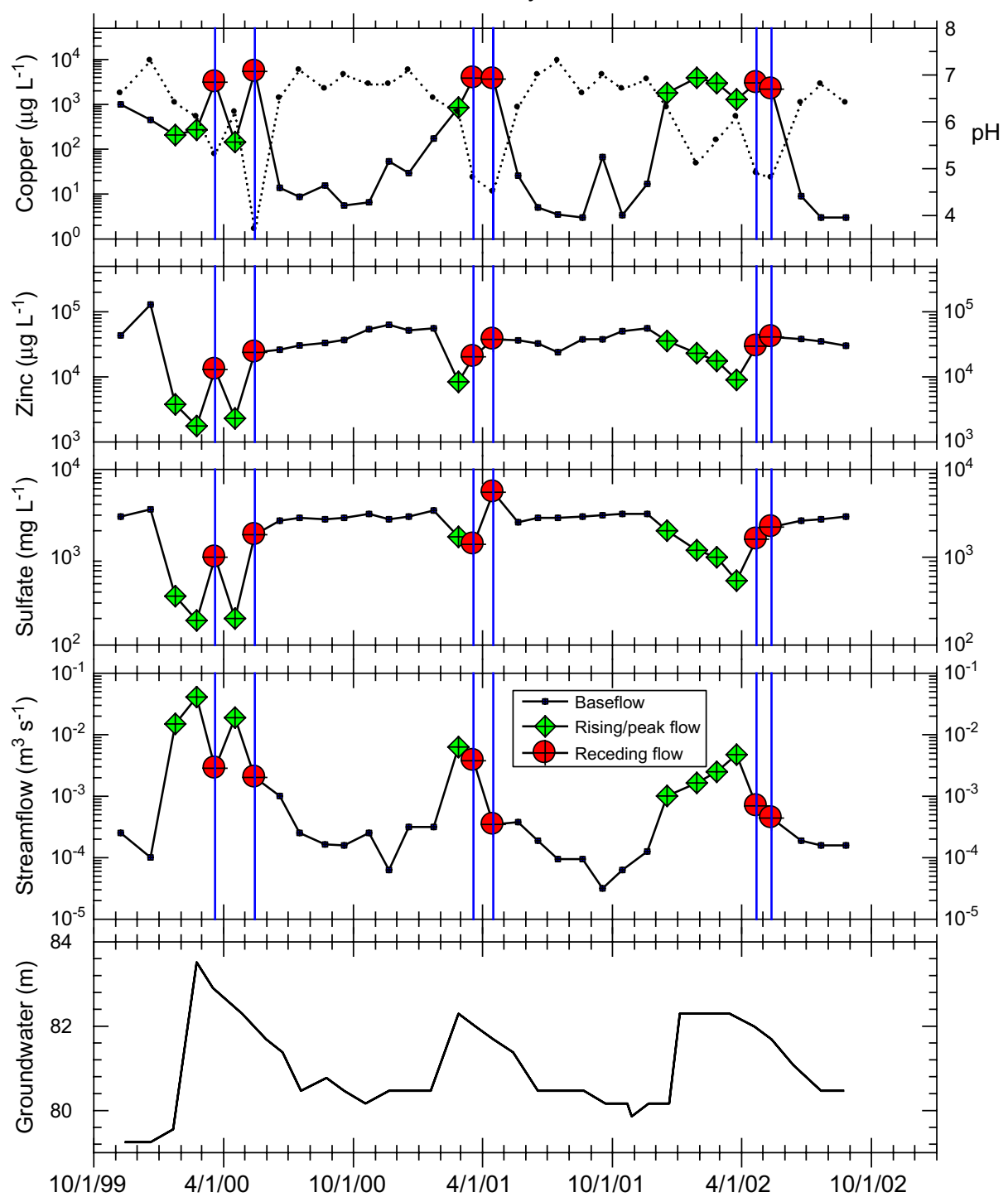

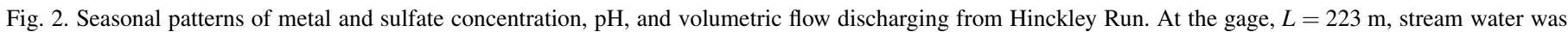

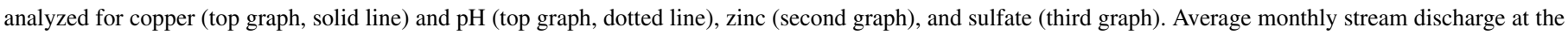

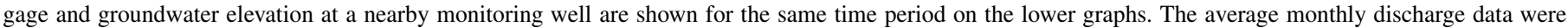

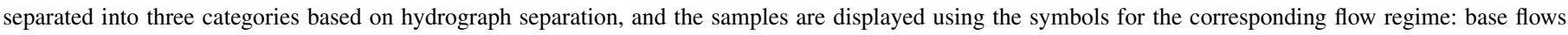

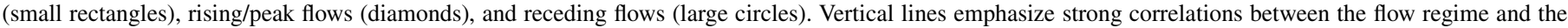
water-quality constituents.

the hypothesis that high stream $\mathrm{pH}$ conditions immobilize copper. The proportion of copper found in the streambed sediment relative to the stream was 2-3 orders of magnitude higher when water $\mathrm{pH}$ was high (Fig. 4). At pH 3 and below, copper concentrations in streambed sediment were approximately 0.01-0.9 times the copper in stream water; whereas at $\mathrm{pH} 6$, copper in sediment was 10-1000 times the concentration of copper in the surface water. This result is consistent with the site restoration design, which included limestone and magnesium carbonate within the channel of Hinckley Run for the purpose of controlling $\mathrm{pH}$ and copper concentrations.

Zinc concentration in the stream increased progressively from upstream to downstream during all sampling events
(Fig. 3). Such a striking contrast between copper and zinc behavior in the stream must be due primarily to the differences in mobility and $\mathrm{pH}$-dependence of binding on mineral substrates, particularly HFO minerals (Dzombak and Morel, 1990; Smith, 1999). This is reflected by the fact that zinc partitioning between stream water and iron-rich sediment did not vary with $\mathrm{pH}$ (data not shown). In addition, as discussed above, during the 1999-2002 post-restoration monitoring, the temporal positions of the relative maxima of copper and zinc did not coincide (Fig. 2). Thus, zinc and copper appear to have distinct sources and certainly different mobility with regard to partitioning between stream water and sediment of the Hinckley Run watershed. In fact, although zinc and copper both originate 


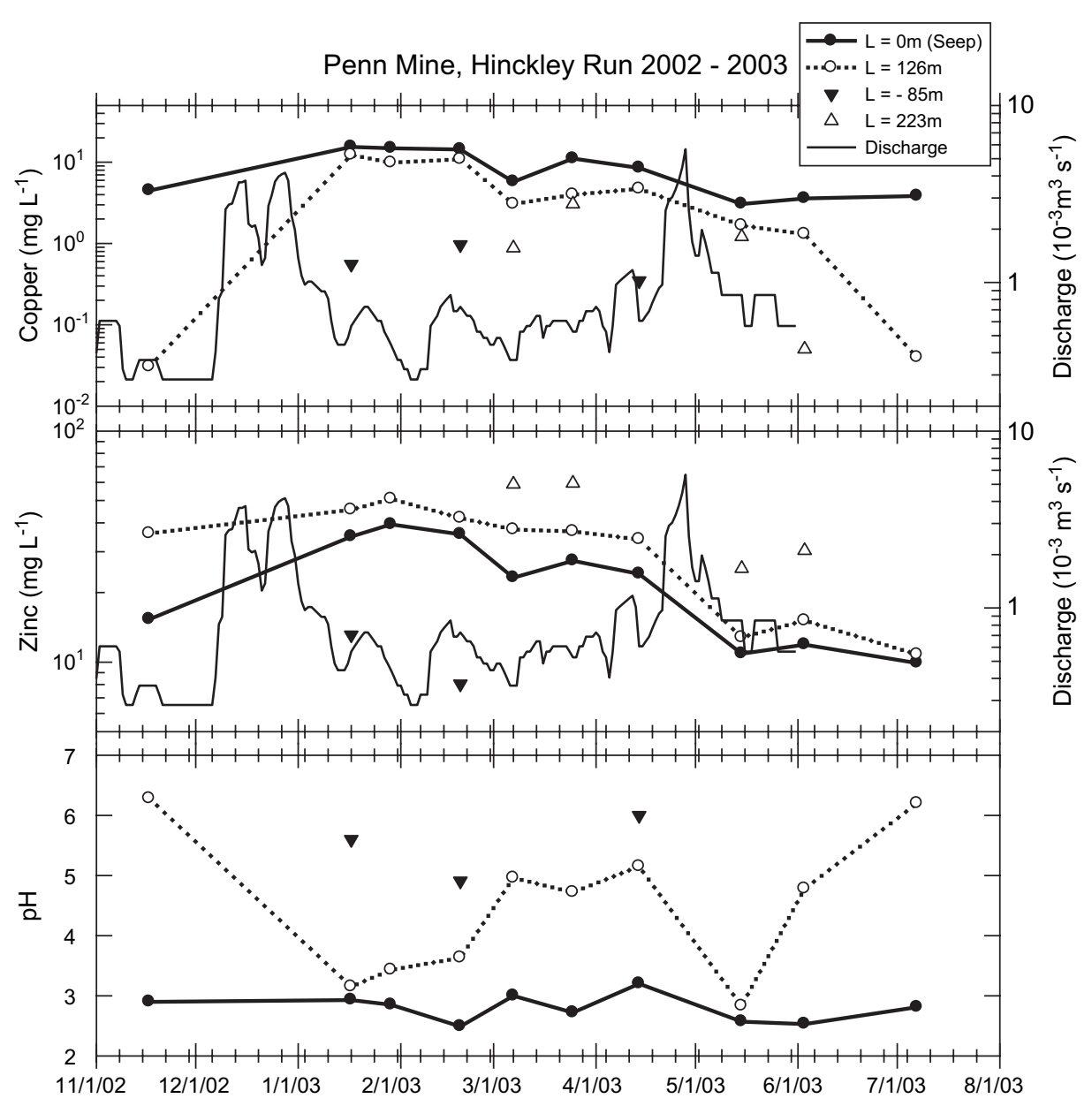

Fig. 3. Spatial variation in seasonal trends revealed at the four sampling sites during the 2002-2003 water year. The sites are $L=-85 \mathrm{~m}$ (solid triangles); $L=0$, seep (solid circles); $L=126 \mathrm{~m}$ (open circles); and $L=223 \mathrm{~m}$ (open triangles). Major tick marks represent months and minor tick marks represent weeks. The graphs show stream discharge and copper concentration (top panel); stream discharge and zinc concentration (middle panel); and stream pH (bottom panel). The temporal trends of $\mathrm{pH}$ differ between the seep and downstream sites, indicating a decrease in copper concentration greater than $95 \%$ over only $126 \mathrm{~m}$ of stream reach during the dry season.

primarily at the seep, another source of zinc is needed to explain the downstream increase in zinc concentration, as discussed below.

\subsection{Mineralogy and chemistry of efflorescent salts}

The most abundant efflorescent sulfate salts observed along the stream banks of Hinckley Run during the dry season were minerals of the hexahydrate group. The hexahydrate group of minerals includes hexahydrate $\left(\mathrm{MgSO}_{4} \cdot 6 \mathrm{H}_{2} \mathrm{O}\right)$ and bianchite $\left(\mathrm{ZnSO}_{4} \cdot 6 \mathrm{H}_{2} \mathrm{O}\right)$. Unit-cell dimensions of hexahydrate and bianchite are sufficiently similar that powder XRD methods could not determine whether (a) both minerals are present as discrete phases, or (b) there is solid-solution substitution of zinc for magnesium in hexahydrate. Wet chemistry indicates that the $\mathrm{Mg} / \mathrm{Zn}$ molar ratio in these salts ranges from 5:1 to $10: 1$. It is possible that the hexahydrite and/or bianchite represents the dehydration product of epsomite $\left(\mathrm{MgSO}_{4} \cdot 7 \mathrm{H}_{2} \mathrm{O}\right)$ and/or goslarite $\left(\mathrm{ZnSO}_{4} \cdot 7 \mathrm{H}_{2} \mathrm{O}\right)$. Also observed in some of the samples was starkeyite $\left(\mathrm{MgSO}_{4} \cdot 4 \mathrm{H}_{2} \mathrm{O}\right)$, likely a dehydration product of hexahydrite. Other minerals identified by XRD and wet chemistry in efflorescent salt samples were tamarugite $(\mathrm{NaAl}$ $\left.\left(\mathrm{SO}_{4}\right)_{2} \cdot 6 \mathrm{H}_{2} \mathrm{O}\right)$, gypsum $\left(\mathrm{CaSO}_{4} \cdot 2 \mathrm{H}_{2} \mathrm{O}\right)$, and calcite $\left(\mathrm{CaCO}_{3}\right)$.

\section{Discussion}

\subsection{Abundance of copper and zinc in Hinckley Run}

During the rainy season, when seep discharge is highest, the seep is able to influence the $\mathrm{pH}$ of the downstream sections of Hinckley Run, increase copper mobility and aqueous concentrations. During the dry season, when the seep discharge is lower, the effects of the seep on stream $\mathrm{pH}$ do not extend as far downstream. Thus the abundance of copper and the relative abundance of copper and zinc are strongly dependent on $\mathrm{pH}$, flow regime, and downstream distance. It was instructive to categorize our measurements based on flow regime, illustrated by different symbols for base flows, increasing and peak flows, and receding flows (see legends for Figs. 2, 5, and 6). Flows characterized as receding were defined to consist of two average monthly flow rates which 


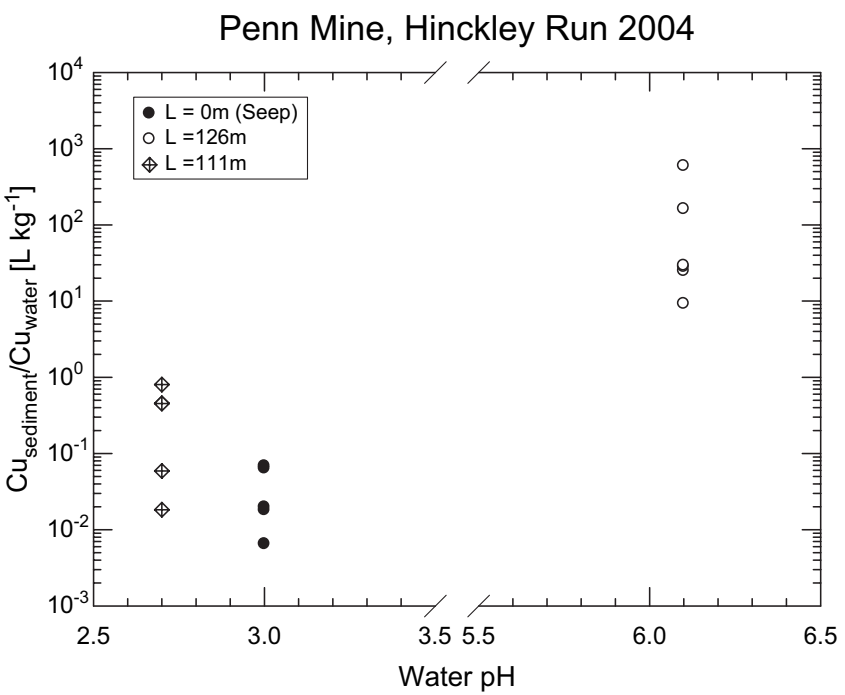

Fig. 4. Partitioning of copper between streambed sediment and stream water. Four to six streambed sediment samples were collected at each of three water sample locations: seep ( $L=0$, solid circles), downstream $(L=111 \mathrm{~m}$, open diamonds), and farther downstream ( $L=126 \mathrm{~m}$, open circles) Negative exponents, denoting more copper in stream water than in sediment, are clustered at $\mathrm{pH}$ 3. At $\mathrm{pH}$ 6.1, two to three orders of magnitude more copper was found in sediment than stream water.

(i) occurred after the seasonal peak, and (ii) were less than the preceding average monthly flow rate. The former requirement was included because during water year 1999-2000, a relative flow rate maximum occurred 2 months after the absolute flow rate maximum (see Fig. 2). Such a categories for flow regime were then also assigned to the copper and zinc concentrations of the grab samples collected during the same month (Fig. 2). Such a classification scheme is consistent with recent studies pointing out that stream chemistry often depends on whether the hydrology corresponds to base flow, rising, or receding discharge values (Soulsby et al., 2000, 2004; Ahearn et al., 2004).

The results of this categorization and the combination of the 1999-2002 and 2002-2003 datasets provide a useful framework to elucidate the behavior of copper and zinc as functions of stream pH. Fig. 5, top panel, shows that aqueous copper in Hinckley Run is highly dependent on stream $\mathrm{pH}$, varies over four orders of magnitude, reaches a maximum during receding flows, and generally decreases with distance downstream from the seep. The plot of aqueous zinc vs. $\mathrm{pH}$ (Fig. 5, bottom panel) illustrates the marked contrast between copper and zinc behavior in Hinckley Run. Unlike copper, aqueous zinc does not vary systematically with stream $\mathrm{pH}$, is consistently high during low flows (dry weather), is diluted during peak flows, and generally increases with downstream distance. Aqueous zinc is on the order of 100 times less variable than copper. Mine waters in the underground workings beneath Hinckley Run are characterized by a $\mathrm{pH}$ value of approximately 4.0 and elevated concentrations of zinc and sulfate with low concentrations of copper (Alpers et al., 1999). Elevated $\mathrm{Zn} / \mathrm{Cu}$ ratios in the underground mine waters are likely caused by preferential scavenging of copper relative to zinc by $\mathrm{H}_{2} \mathrm{~S}$ produced by sulfate-reducing bacteria (Church et al., 2005). Thus the downstream sites in Hinckley Run are probably affected by seepage of zinc-sulfate-rich, copperpoor water from the deep mine workings.

Geochemical and microbiological studies have highlighted the importance of seasonality in understanding hydrogeologic systems and ecosystems (Alpers et al., 1994, 2003; Holloway and Dahlgren, 2001; Baker and Banfield, 2003). Efflorescent salts containing metals and sulfate tend to precipitate during dry periods and to dissolve during wet periods. The partitioning of trace metals into the crystalline salts can have dramatic effects on aqueous geochemistry, including the $\mathrm{Zn} / \mathrm{Cu}$ ratio (Alpers et al., 1994). The abundance, chemistry, and geometry of the efflorescent salt deposits observed in July 2004 indicate that the salt formation may be responsible for some removal of magnesium, zinc, aluminum and sulfate from Hinckley Creek waters, but the salts were likely not a major control on stream geochemistry in this system during low-flow conditions. A pronounced "first flush" effect caused by rapid salt dissolution would be expected to result in higher in-stream concentrations of sulfate, magnesium, zinc, aluminum and other metals in response to the first rainstorm event after extended dry periods, but such an event was not sampled in the present investigation.

During low-flow conditions the concentration of zinc was rather constant, whereas copper concentrations varied over two orders of magnitude, resulting in values of $\mathrm{Zn} / \mathrm{Cu}$ from approximately 250 to 15,000 (a range of variation of 60 -fold) (Fig. 6). The other two flow regimes (rising and peak flows, and receding flows) were subject to much less variable and lower values of $\mathrm{Zn} / \mathrm{Cu}$, approximately 150 times lower than base flow values, and a smaller range of variation, within a factor of 5. Together Figs. 5 and 6 indicate that: (i) when relatively high stream $\mathrm{pH}$ values immobilize copper in streambed sediments, zinc dominates stream chemistry (with concentrations typically 4000 times greater than copper); (ii) $\mathrm{Zn} / \mathrm{Cu}$ and $\mathrm{pH}$ are highest downstream during dry weather (low-flow) periods when the rate of discharge from the seep is likely to be at a minimum; (iii) downstream from the seep, $\mathrm{Zn} / \mathrm{Cu}$ and $\mathrm{pH}$ are lowest during receding flows; (iv) $\mathrm{Zn} / \mathrm{Cu}$ is lowest and steadiest at the seep; (v) $\mathrm{pH}$ at the seep is relatively low and steady but generally much higher and more variable downstream; and (vi) $\mathrm{Zn} / \mathrm{Cu}$ increases with distance downstream from the seep because of binding of copper by poorly crystalline hydrous ferric oxides on the stream bed, coupled with increased $\mathrm{Zn}$ inputs.

The presence of a steady, relatively homogeneous plume of acidic groundwater feeding the seep could cause the observed narrow range in ratio $\mathrm{Zn} / \mathrm{Cu}$ and $\mathrm{pH}$ at the seep throughout the year. During low-flow conditions, copper is bound to streambed sediments, as intended by the restoration efforts, whereas zinc continues to be added to the stream from additional ground-water seepage sources, and the zinc is not bound to streambed sediments as effectively as copper because of its sorption properties (Dzombak and Morel, 1990).

Maxima in copper concentration and minima in $\mathrm{pH}$ coincided with receding limbs of the discharge hydrograph. This suggests that, relative to precipitation and runoff, seepage through the mineralized bedrock (or directly from mine 


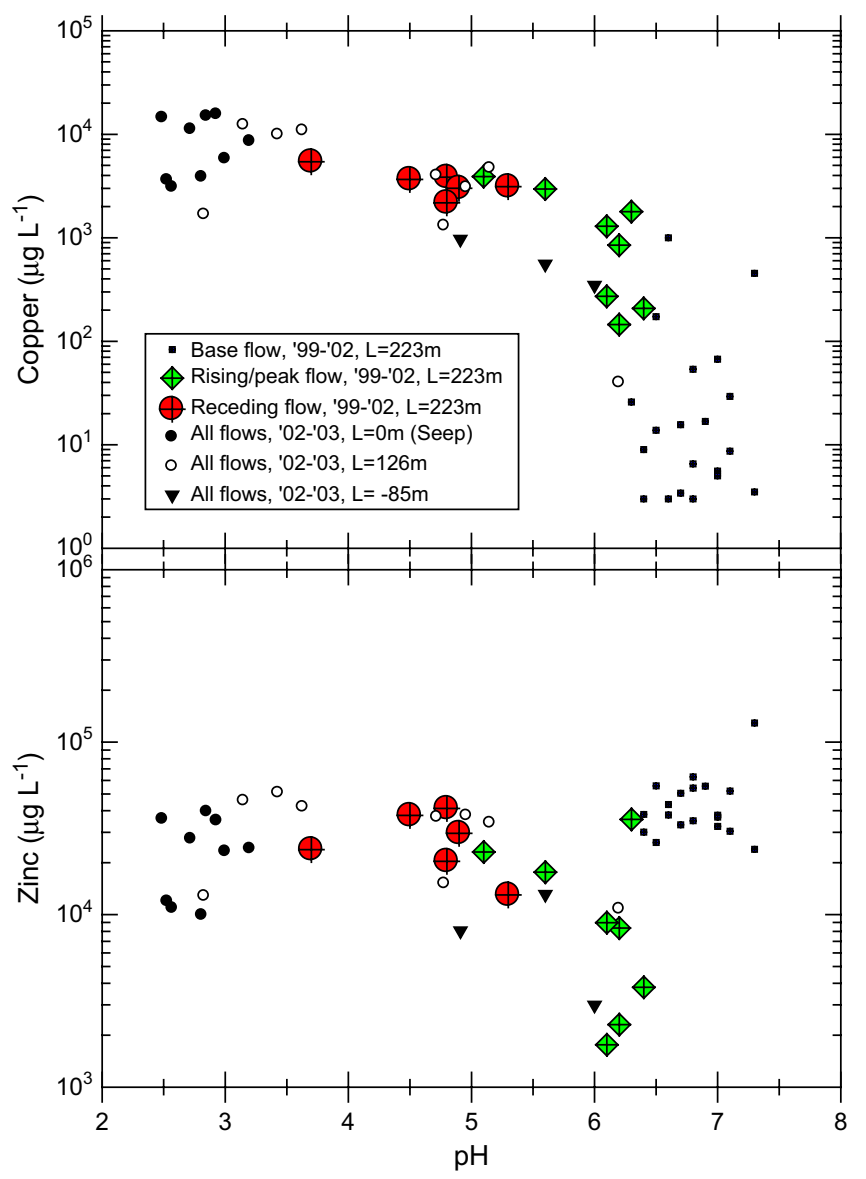

Fig. 5. Relation of copper and zinc concentration to stream $\mathrm{pH}$. Plots of copper vs. $\mathrm{pH}$ (top, 6A) and zinc vs. pH (bottom, 6B) show the relation between metal mobility and stream $\mathrm{pH}$ is highly metal-specific. The 1999-2002 post-restoration monitoring grab samples from $L=223 \mathrm{~m}$ (CH2M Hill, 2003) were separated into three categories based on the flow regime as described for Fig. 2. The 2002-2003 data collected by the authors were used to investigate the influence of spatial location on metal abundance and $\mathrm{pH}$; legends for three locations are as for Fig. 3.

workings) provided a relatively greater contribution to streamflow as precipitation declined.

\subsection{Comparison to other streams}

Several recent articles (e.g. Soulsby et al., 2000, 2004; Ahearn et al., 2004; Gammons et al., 2005) have reviewed the influences of stream discharge, sunlight, temperature, groundwater composition, and soil solution chemistry on metal concentrations in streams. They conclude that complex models, with chemically distinct hydrological source areas and flow paths, are needed to explain the patterns of stream chemistry on different spatial and temporal scales. Geological components may dominate base flows, and groundwater generally mixes with, or is displaced by, hillslope drainage during storms.

Studying the Cosumnes River, Ahearn et al. (2004) identified three seasonal flow regimes in watersheds of the Sierra foothills of California: baseflow (July-October), stormflow
(November-March), and meltflow (April-July). Each of these flow regimes generally correspond to distinct ranges of ionic abundance in runoff, and thus surface water quality is largely a function of watershed hydrology. Although meltflow does not apply to the Hinckley Run watershed because of its relatively low elevation, our results support the notion that seasonal variations in flow rate force large differences in surface water quality. Our study was not designed to address the flushing effect of storm events. At the time scale of our observations in the Hinckley Run watershed, no flushing effect was observed for copper and zinc. Zinc was diluted by early increases in surface water runoff; maximum copper concentrations and minimum $\mathrm{pH}$ values were observed 1-2 months after maximum seasonal flow rates. Such a lag does not correspond to any of the conceptual models reported by Ahearn et al. (2004).

Other researchers have observed similar concentration maxima that lagged peak flow rates. In a rehabilitated, industrialized catchment in Wales, where aqueous copper was associated with fine sediment, copper peaked with storm discharge whereas the peak in aqueous zinc lagged on a time scale of hours (Blake et al., 2003). However, the lag in Hinckley Run and the lag in Wales imply different conceptual models, as (i) Hinckley Run is hydraulically connected to underground mine workings, and (ii) Blake et al. (2003) focused on storm events, for which we have no data.

A particularly relevant comparison is to Sanae Creek, affected by acid mine drainage in Korea (Kim et al., 2003). At Sanae Creek, heavy rainfall in the late summer season penetrates into a coal waste dump, where sulfides gradually react with water, causing a decrease in $\mathrm{pH}$ and an increase in the dissolved metals of the stream water. Heavy rainfall in September is followed by minimal rainfall in October. Aqueous zinc and sulfate concentrations are high near the mine sources and peak temporally with rainfall in September. Aqueous iron, similar to copper in Hinckley Run, peaks in concentration after rainfall subsides in October and precipitates in sediments downstream as stream $\mathrm{pH}$ increases.

In the Hinckley Run watershed, our observation that copper is highest and $\mathrm{pH}$ is lowest in receding flows may be explained by important early contributions of precipitation and runoff/interflow through macropores which are mostly vacant during dry weather, followed by a larger contribution from pore water that had longer periods of contact with weathered bedrock and/or pyritic soils. In the mineralized environment of Hinckley Run, such prolonged contact with oxidizing sulfide minerals could result in lower $\mathrm{pH}$ and higher copper concentrations.

\section{Conclusions}

Our results are consistent with those from other recent studies (Kim et al., 2003; Munk and Faure, 2004; Soulsby et al., 2004) that show strong spatial variation in stream chemistry in small catchments. Even for sites separated by less than $100 \mathrm{~m}$, separate, chemically distinct sources of groundwater and the presence of iron-rich, benthic sediments 


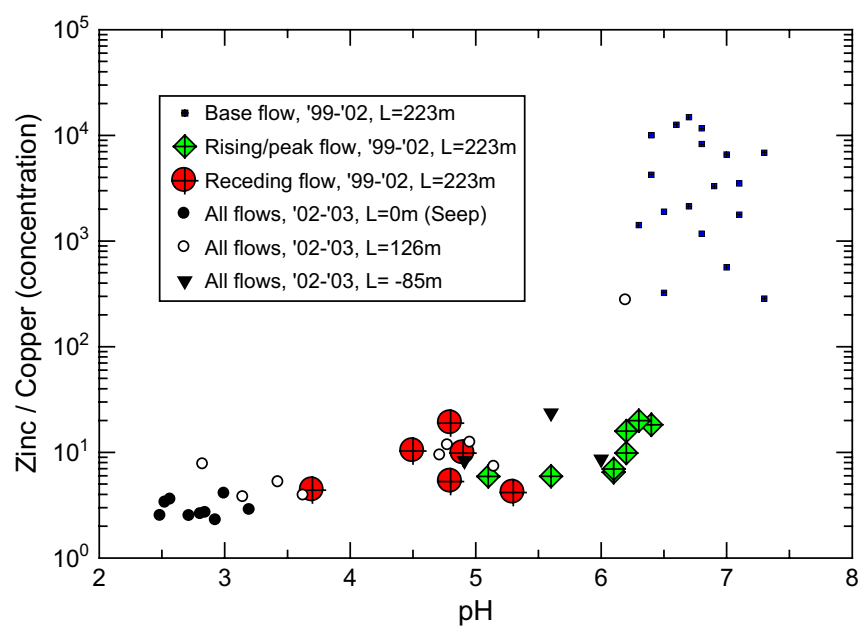

Fig. 6. Dependence of the $\mathrm{Zn} / \mathrm{Cu}$ ratio on $\mathrm{pH}$. Symbols (same as for Fig. 5) reveal systematic variation with flow regime and location.

may dramatically affect stream parameters such as $\mathrm{pH}$ and species-specific metal abundance. Monitoring water quality at the outlet of watersheds can provide important information about net contaminant loading, but collection of water samples at multiple sites along a watercourse, even in small watersheds, may offer significant insight about the mechanisms controlling hydrogeochemistry. Here, by combining several months of high spatial-resolution (longitudinal scale of $\sim 100 \mathrm{~m}$ ) monitoring of Hinckley Run with long-term monitoring performed at the watershed outlet, we were able to illustrate that distinct sources and sinks control copper and zinc abundance in the stream and affect loading rates to a nearby reservoir.

In addition to spatial considerations, our results also raise questions about the adequacy of water-quality monitoring efforts that focus on pollutant transport that occurs on the rising limb and/or peak of the seasonal hydrograph (i.e. beginning and middle of the wet season). By categorizing our water-quality measurements based on the corresponding flow regime (base, rising-peak, and receding flows), the effect of seasonal hydrology on metals abundance was highlighted. Groundwater sources in our study area became dominant on the order of 2 months after peak surface-water discharge, resulting in a lag between peaks in stream flow and metal concentrations. Therefore, it should not be assumed that water quality is steady during receding seasonal flows; even in arid environments, monitoring efforts should characterize the receding flow regime in addition to rising, peak, and base flows.

\section{Acknowledgments}

Grant 00-35100-9531 from the NRI competitive grants program/USDA to W.K.S. provided support to D.G.B. for his graduate study. Professor Thomas Young (UC Davis) gave helpful guidance and access to the ICP-MS. Cory Mitchell and Christopher Tzeng (UC Davis) gave technical assistance with soil and plant collection and analysis. Kelly Rider and
Jerry Harmon (USGS) assisted with field work in July 2004. John Neil (UC Davis) assisted with X-ray diffraction. The use of trade, product, industry, or firm names in this report is for descriptive purposes only and does not constitute endorsement of products by the U.S. Government.

\section{References}

Ahearn, D.S., Sheibley, R.W., Dahlgren, R.A., Keller, K.E., 2004. Temporal dynamics of stream water chemistry in the last free-flowing river draining the western Sierra Nevada, California. Journal of Hydrology 295, 47-63.

Alpers, C.N., Nordstrom, D.K., Thompson, J.M., 1994. Seasonal variations in the $\mathrm{Zn} / \mathrm{Cu}$ ratio of acid mine drainage from Iron Mountain, California. In: Alpers, C.N., Blowes, D.W. (Eds.), Environmental Geochemistry of Sulfide Oxidation. American Chemical Society, Washington DC, ACS Symposium Series 550, 324-344.

Alpers, C.N., Hamlin, S.N., Hunerlach, M.P., 1999. Hydrogeology and geochemistry of acid mine drainage in ground water in the vicinity of Penn Mine and Camanche Reservoir, California, Summary Report, 1993-95. U.S. Geological Survey Water-Resources Investigations Report 96-4287, 59 pp.

Alpers, C.N., Hunerlach, M.P., Hamlin, S.N., Zierenberg, R.A., 2003. Reconnaissance of Acid Drainage Sources and Preliminary Evaluation of Remedial Alternatives at the Copper Bluff Mine, Hoopa Valley Reservation, California. U.S. Geological Survey, Water-Resources Investigations Report 02-4253, 53 pp. $<$ http://pubs.water.usgs.gov/wri024253>

Baker, B.J., Banfield, J.F., 2003. Microbial communities in acid mine drainage. FEMS Microbiology and Ecology 44, 139-152.

Bambic, D.G., 2003. Hydrobiogeochemical Cycling of $\mathrm{Cu}$ and $\mathrm{Zn}$ near an AMD-Affected Stream. Master's thesis, University of California, Davis.

Blake, W.H., Walsh, R.P.D., Barnsley, M.J., Palmer, G., Dyrynda, P., James, J.G., 2003. Heavy metal concentrations during storm events in a rehabilitated industrialized catchment. Hydrological Processes 17, 1923-1939.

CH2M Hill, 2000. Post-Restoration Final Effectiveness Monitoring Report, Penn Mine Environmental Restoration Project. Prepared for East Bay Municipal Utility District (Oakland, Calif.) and Regional Water Quality Control Board-Central Valley Region (Rancho Cordova, Calif.), December 2000.

CH2M Hill, 2001. Second Annual Post-Restoration Effectiveness Monitoring Report, Penn Mine Environmental Restoration Project. Prepared for East Bay Municipal Utility District (Oakland, Calif.) and Regional Water Quality Control Board-Central Valley Region (Rancho Cordova, Calif.), November 2001

CH2M Hill, 2003. Third Annual Post-Restoration Effectiveness Monitoring Report, Penn Mine Environmental Restoration Project. Prepared for East Bay Municipal Utility District (Oakland, Calif.) and Regional Water Quality Control Board-Central Valley Region (Rancho Cordova, Calif.), 25 pp. plus tables, figures, and appendices, February 2003

Church, C.D., Alpers, C.N., Rye, R.O., Wilkin, R.T., 2005. Evidence for metal attenuation in acid mine water by sulfate reduction, Penn Mine, Calaveras County, California (abstract). Program with Abstracts, 86th Annual meeting, Pacific Division, American Association for the Advancement of Science, Ashland, OR, June 12-16, 2005.

Clark, W.B., Lydon, P.A., 1962. Mines and mineral resources of Calaveras County, California, California Division of Mines and Geology, County Report 2, 214 pp.

Dzombak, D.A., Morel, F.M.M., 1990. Surface Complexation ModelingHydrous Ferric Oxide. Wiley, New York, 393 pp.

Finlayson, B.J., Rectenwald, H.J., 1978. Toxicity of Copper and Zinc from the Penn Mine Area on King Salmon (Oncorhynchus Tshawytscha) and Steelhead Trout (Salmo Gairdneri) in the Mokelumne River Basin, California. California Department of Fish and Game, Environmental Services Branch, Administrative Report 78-1, 42 pp.

Gammons, C.H., Nimick, D.A., Parker, S.R., Cleasby, T.E., McCleskey, R.B., 2005. Diel behavior of iron and other heavy metals in a mountain stream with acidic to neutral $\mathrm{pH}$ : Fisher Creek, Montana, USA. Geochimica et Cosmochimica Acta 69 (10), 2505-2516. 
Holloway, J.M., Dahlgren, R.A., 2001. Seasonal and even-scale variations in solute chemistry for four Sierra Nevada catchments. Journal of Hydrology $250,106-121$.

Jambor, J.L., Nordstrom, D.K., Alpers, C.N., 2000. Metal-sulfate salts from sulfide mineral oxidation. In: Alpers, C.N., Jambor, J.L., Nordstrom, D.K. (Eds.), Sulfate Minerals: Crystallography, Geochemistry, and Environmental Significance. Mineralogical Society of America and Geochemical Society, Washington DC. Reviews in Mineralogy and Geochemistry 40, 303-350.

Kim, J.J., Kim, S.J., Choo, C.O., 2003. Seasonal change of mineral precipitates from the coal mine drainage in the Taebaek coal field, South Korea. Geochemical Journal 37, 109-121.

Munk, L.A., Faure, G., 2004. Effects of pH fluctuations on potentially toxic metals in the water and sediment of the Dillon Reservoir, Summit County, Colorado. Applied Geochemistry 19, 1065-1074.

Parsons, M.B., Bird, D.K., Einaudi, M.T., Alpers, C.N., 2001. Geochemical and mineralogical controls on trace element release from the Penn Mine base-metal slag dump. Applied Geochemistry 16, 1567-1593.

Peterson, J.A., 1985. Geologic map of the Penn Mine, Calaveras County, California: U.S. Geological Survey Miscellaneous Field Studies Map, MF-1797, scale 1:1200, 2 sheets.

Silk, W.K., Bambic, D.G., O’Dell, R.E., Green, P.G., 2006. Seasonal and spatial patterns of metals at a restored copper mine site II. Copper in riparian soils and Bromus carinatus shoots. Environmental Pollution 144 (3), 793-799.
Smith, K.S., 1999. Metal sorption on mineral surfaces: An overview with examples relating to mineral deposits. In: Plumlee, G.S., Logsdon, M.J. (Eds.), The Environmental Geochemistry of Mineral Deposits. Part A. Processes, Methods, Health Issues, Society of Economic Geologists. Reviews in Economic Geology 6A, 161-182.

Soulsby, C., Malcolm, R., Helliwell, R., Ferrier, R.C., Jenkins, A., 2000. Isotope hydrology of the Allt a'Mharcaidh catchment, Cairngorms, Scotland: implications for hydrological pathways and residence times. Hydrological Processes 14, 747-762.

Soulsby, C., Rodgers, P.J., Petry, J., Hannah, D.M., Malcolm, I.A., Dunn, S.M., 2004. Using tracers to upscale flow path understanding in mesoscale mountainous catchments: two examples from Scotland. Journal of Hydrology 291, 174-196.

U.S. Environmental Protection Agency (USEPA), August 1993. Methods for the Determination of Inorganic Substances in Environmental Samples. EPA/600/R-93/100. Environmental Monitoring Systems Laboratory, Office of Research and Development, Cincinnati, Ohio 45268.

U.S. Environmental Protection Agency (USEPA), May 1994. Methods for the Determination of Metals in Environmental Samples. EPA/600/R-94/100. Environmental Monitoring Systems Laboratory, Office of Research and Development, Cincinnati, Ohio 45268.

U.S. Environmental Protection Agency (USEPA), 1997. Federal Register 40 CFR Part 131: Water Quality Standards; Establishment of Numeric Criteria for Priority Toxic Pollutants for the State of California; Proposed Rule, Part II. 